\title{
Genetic Transformation of Garlic (Allium sativum L.) by Particle Bombardment
}

\section{Alejandrina Robledo-Paz, ${ }^{1}$ José Luis Cabrera-Ponce, ${ }^{2}$ Víctor Manuel Villalobos-Arámbula, ${ }^{3}$ Luis Herrera-Estrella, ${ }^{3}$ and Alba Estela Jofre- Garfias $^{4}$}

Departamento de Ingeniería Genética de Plantas, Centro de Investigación y de Estudios Avanzados del I.P.N. Km, 9.6 libramiento Norte Carretera IrapuatoLeón, Apdo. Postal 629, 36500 Irapuato, Gto, México

Additional index words. biolistic, transgenic plants, somatic embryogenesis, genetic engineering, tissue culture

\begin{abstract}
Microprojectile bombardment was used to introduce DNA into embryogenic callus of garlic (Allium sativum L.) and produce stably transformed garlic plants. Embryogenic calluses, derived from garlic cultivar 'GT96-1', were bombarded with plasmid DNA containing genes coding for hygromycin phosphotransferase and $\beta$-glucuronidase. Putatively transformed calluses were identified in the bombarded tissue after 4 months of selection on $20 \mathrm{mg} \cdot \mathrm{L}^{-1}$ hygromycin $B$. The transgenic nature of the selected material was demonstrated by GUS histochemical assay and Southern blot hybridization analysis, and twenty transgenic plants were regenerated.
\end{abstract}

Garlic (Allium sativum L.), family Alliaceae (Takhtahan, 1997), is a monocotyledonous crop used worldwide both as a condiment and for its medicinal properties. This crop is susceptible to numerous diseases caused by fungi, viruses, nematodes and insect pests. Garlic does not readily produce seeds, and is propagated vegetatively with a low multiplication rate. This mode of reproduction facilitates disease transfer (Novak, 1990) and prevents improvement of garlic by traditional breeding methods.

Both Agrobacterium and particle bombardment, have proven to be very useful techniques for the generation of transgenic plants of both dicotyledoneous and monocotyledoneus species (Bommineni et al., 1993; Bower and Birch, 1992; Cabrera-Ponce et al., 1995, 1997; Casas et al., 1993; Chee and Slightom, 1992; Christou, 1995; Eady, 2001; Eady et al., 2000; Fromm et al., 1990; Hiei et al., 1994; Ishida et al., 1996; Kihara et al., 1998; McCabe et al., 1988; Russell et al., 1993; Thomas et al., 1994; Vain et al., 1998). The use of genetic engineering techniques to obtain cultivars of garlic harbouring genes for pathogen resistance will surely have an impact on garlic production.

Received for publication $10 \mathrm{Feb} .2003$. Accepted for publication 9 Dec. 2003. We want to thank Claudia Geraldine León Ramírez, Nélida Vázquez Sánchez and Rosa María Adame Alvarez for their technical assistance. This work was supported by Colegio de Postgraduados, Montecillo, México and The National Council for Science and Technology (CONACYT, México) by means of a Graduate Scholarship to ARP and a grant (28534N, awarded to AEJG).

${ }^{1}$ Former graduate student. Current address: Instituto de Recursos Genéticos y Productividad, Colegio de Postgraduados. Km. 36.5 Carretera México-Texcoco. Apdo.Postal56230, Montecillo,Edo, México; e-mail arobledo@colpos.mx.

${ }^{2}$ Research assistant.

${ }^{3}$ Full profesor.

${ }^{4}$ Associated professor. To whom correspondence should be addressed; ajofre@ ira.cinvestav.mx.
Onion and garlic are among commercially important crops for which it has been possible, although difficult, to obtain transgenic plants. To date there are only a few reports of transient expression (Barandiaran et al., 1998; Eady et al., 1996) and stable genetic transformation of these species (Kondo et al., 2000, Myers and Simon, 1998).

Here we describe a reliable and efficient protocol to obtain transgenic garlic plants employing callus tissue derived from root by particle bombardment.

\section{Materials and Methods}

Induction of somatic embryogenesis. Cloves of garlic cultivar 'GT96-1' were separated from the bulb and peeled before treatment with a chlorinated solution (1.8\% active chlorine) for $20 \mathrm{~min}$. Treated cloves were rinsed three times in sterilized distilled water.

Disinfected cloves were placed on a sprouting medium prepared with half the concentraand Skoog (MS) medium (Murashige and Skoog, 1962) and supplemented with 0.029 $\mathrm{M}$ sucrose and $7 \mathrm{~g} \cdot \mathrm{L}^{-1}$ Phytagar (Gibco, BRL), pH 5.8 (medium A). The cloves were subsequently incubated at $24 \pm 2{ }^{\circ} \mathrm{C}$ under 16 $\mathrm{h}$ daily illumination $\left(50 \mu \mathrm{mol} \cdot \mathrm{m}^{-2} \cdot \mathrm{s}^{-1}\right)$. After three days, 3-mm-long root tip segments were cut with a scalpel and cultured in $100 \times$ 15 -mm petri dishes (15 segments per plate) containing medium B to induce embryogenic calluses. This medium was prepared with salts from Chu et al. (1975) (medium N6), vitamins from Eriksson (1965), $0.058 \mathrm{~m}$ sucrose, $6 \mathrm{~mm}$ L-proline, 8 g. $\mathrm{L}^{-1}$ Phytagar, as well as 1.0 $\mathrm{mg} \cdot \mathrm{L}^{-1}$ of 2,4-D. Root tips were cultured for 8 weeks at $24 \pm 2{ }^{\circ} \mathrm{C}$ in complete darkness. Embryogenic calluses were either maintained on medium $\mathrm{B}$ or subcultured onto medium $\mathrm{C}$ to explants as target tissues for transformation tion of salts and vitamins found in Murashige induce the development of somatic embryos. Medium $\mathrm{C}$ was prepared with the salts and vitamins of MS medium and $1.0 \mathrm{mg} \cdot \mathrm{L}^{-1}$ of N6-benzyladenine (BA) plus sucrose 0.058 $\mathrm{M}$ and Phytagar $7 \mathrm{~g} \cdot \mathrm{L}^{-1}$. Cultures were incubated at $24{ }^{\circ} \mathrm{C}$ under $16 \mathrm{~h}$ daily illumination $\left(50 \mu \mathrm{mol} \cdot \mathrm{m}^{-2} \cdot \mathrm{s}^{-1}\right)$. Embryogenic calluses were cultured for 6 weeks on this medium and then transferred to medium D (similar to medium $\mathrm{C}$ but devoid of growth regulators).

DNA (plasmids). The plasmid used for the bombardment experiments (pWRG1515) contains the hygromycin phosphotransferase (hph) and the b-glucuronidase (gusA) genes under control of the cauliflower mosaic virus $35 \mathrm{~S}$ (CaMV35S) promoter and the 3 ' region of the nopaline synthase gene ( 3 'NOS) (Christou et al., 1991). The plasmid was amplified in E. coli, and extracted and purified by alkaline lysis as described by Birnboim and Doly (1979). Purified DNA was resuspended in sterile distilled water and adjusted to $1 \mu \mathrm{g} \cdot \mu \mathrm{L}^{-1}$ for bombardments.

Bombardment procedure. The plasmid was precipitated onto M10 $(0.73 \mu \mathrm{m})$ tungsten particles as described by Tomes et al. (1995) using the following mixture: $50 \mu \mathrm{L}$ of tungsten particle suspension $\left(15 \mathrm{mg} \cdot \mathrm{mL}^{-1}\right) ; 5 \mu \mathrm{L}$ pWRG1515 $\left(1 \mu \mathrm{g} \cdot \mu \mathrm{L}^{-1}\right) ; 50 \mu \mathrm{L} 2.5 \mathrm{M} \mathrm{CaCl}_{2}$ and $20 \mu \mathrm{L} 0.1 \mathrm{~m}$ spermidine.

Mixtures were sonicated briefly and then centrifuged at $10,800 g_{n}$ for $10 \mathrm{~s}$. The supernatant was removed and the pellet was resuspended in $60 \mu \mathrm{L}$ absolute ethanol and aliquots of $10 \mu \mathrm{L}$ were delivered to each macrocarrier. Embryogenic calluses were bombarded using a PDS-1000 He particle delivery system (Sanford et al., 1991) at 800 PSI rupture disk pressure. Embryogenic calluses $(300 \mathrm{mg}$ of fresh weight) were placed in the center of each petri plate containing medium $\mathrm{B}$, and the sample chamber was evacuated to $0.07 \mathrm{~atm}$. The distance between the rupture membrane and the macrocarrier was $1.2 \mathrm{~cm}$, flight distance was $1.2 \mathrm{~cm}$, and calluses were placed at $7.0 \mathrm{~cm}$ from the microparticle launching point.

GUS assays. Transient gusA gene expression was assayed $24 \mathrm{~h}$ after bombardment. Calluses were incubated in $100 \mu \mathrm{L}$ reaction buffer containing $0.5 \mathrm{mg} \cdot \mathrm{mL}^{-1}$ of 5-bromo-4chloro-3-indolyl $\beta$-D-glucuronide (X-gluc) at $37^{\circ} \mathrm{C}$ (McCabe et al., 1988). Blue spots were counted using a stereo microscope.

Selection oftransgenic clones. Bombarded calluses were maintained on medium B for 9 $\mathrm{d}$ before being transferred to medium $\mathrm{B}$ plus $20 \mathrm{mg} \cdot \mathrm{L}^{-1}$ of hygromycin $\mathrm{B}$. Tissues were subcultured on fresh medium until control (nonbombarded tissues) did not grow (16 weeks), and proliferation of putative transgenic embryogenic calluses was observed.

Resistant embryogenic calluses were subcultured on medium $\mathrm{C}$ with hygromycin $\mathrm{B}$ to induce embryo development. Regenerated plantlets were transferred to medium D plus hygromycin B to obtain shoot and root elongation.

Southern blot analysis. Total genomic DNA from transgenic and wild type calluses were isolated following the method of Shure et al. (1983). DNA $(20 \mu \mathrm{g})$ was digested with $E c o R \mathrm{I}$ 
for hybridizations with the $h p h$ gene. This enzyme liberates a 1.3-kbp fragment. Digested DNAs were separated on $1 \%$ agarose gels and transferred to nylon membranes (Hybond-N+, Amersham) using $2 \times \mathrm{SSC}$ buffer $(3 \mathrm{M} \mathrm{NaCl}$ and $0.3 \mathrm{~m}$ sodium citrate, $\mathrm{pH}$ 7.0). Membranes were prehybridized for $6 \mathrm{~h}$ at $65^{\circ} \mathrm{C}$ in $2 \mathrm{M}$ $\mathrm{NaCl} ; 0.6 \mathrm{M} \mathrm{NaH} \mathrm{PO}_{4} ; 0.02$ м EDTA $\bullet \mathrm{Na}_{2} ; 96$ $\mathrm{mg} \cdot \mathrm{mL}^{-1}$ dextran sulfate; $9.6 \mathrm{mg} \cdot \mathrm{mL}^{-1}$ sarkosyl; $0.52 \mathrm{mg} \cdot \mathrm{mL}^{-1}$ heparin; $1.9 \mathrm{mg} \cdot \mathrm{mL}^{-1}$ skimmed milk; $0.077 \mathrm{mg} \cdot \mathrm{mL}^{-1}$ sodium azide according to Sambrook et al. (1989). Hybridizations were carried out with a 1.6-kbp hph XbaI fragment from pWRG1515. This fragment was used in random priming reactions to generate the labeled probe (Feinberg and Vogelstein, 1983). Filters were washed in $2 \times$ SSC, $0.5 \%$ SDS at $65^{\circ} \mathrm{C}$ for $1 \mathrm{~h}$. Autoradiography was carried out using Kodak X-OMAT-AR film for $24 \mathrm{~h}$ at $-70{ }^{\circ} \mathrm{C}$.

\section{Results and Discussion}

Tissue culture of garlic. Garlic root-tip segments started to swell after $15 \mathrm{~d}$ of culture on induction medium B. Subsequently, cellular proliferation began and was limited to the cambial zone, resulting in the formation of distinct calluses by the end of the eighth week. Callus mass and size increased considerably upon transfer to medium $\mathrm{C}$, and globular somatic embryos developed after 3 weeks. Embryos at the torpedo stage were easily discernible after 5 to 6 weeks of culture on medium C. These cultures were maintained in the same medium with a high capacity for the production of somatic embryos for at least 2 years. Embryos at the torpedo stage that were subcultured on medium $\mathrm{B}$ for 1 to 2 months proliferated by
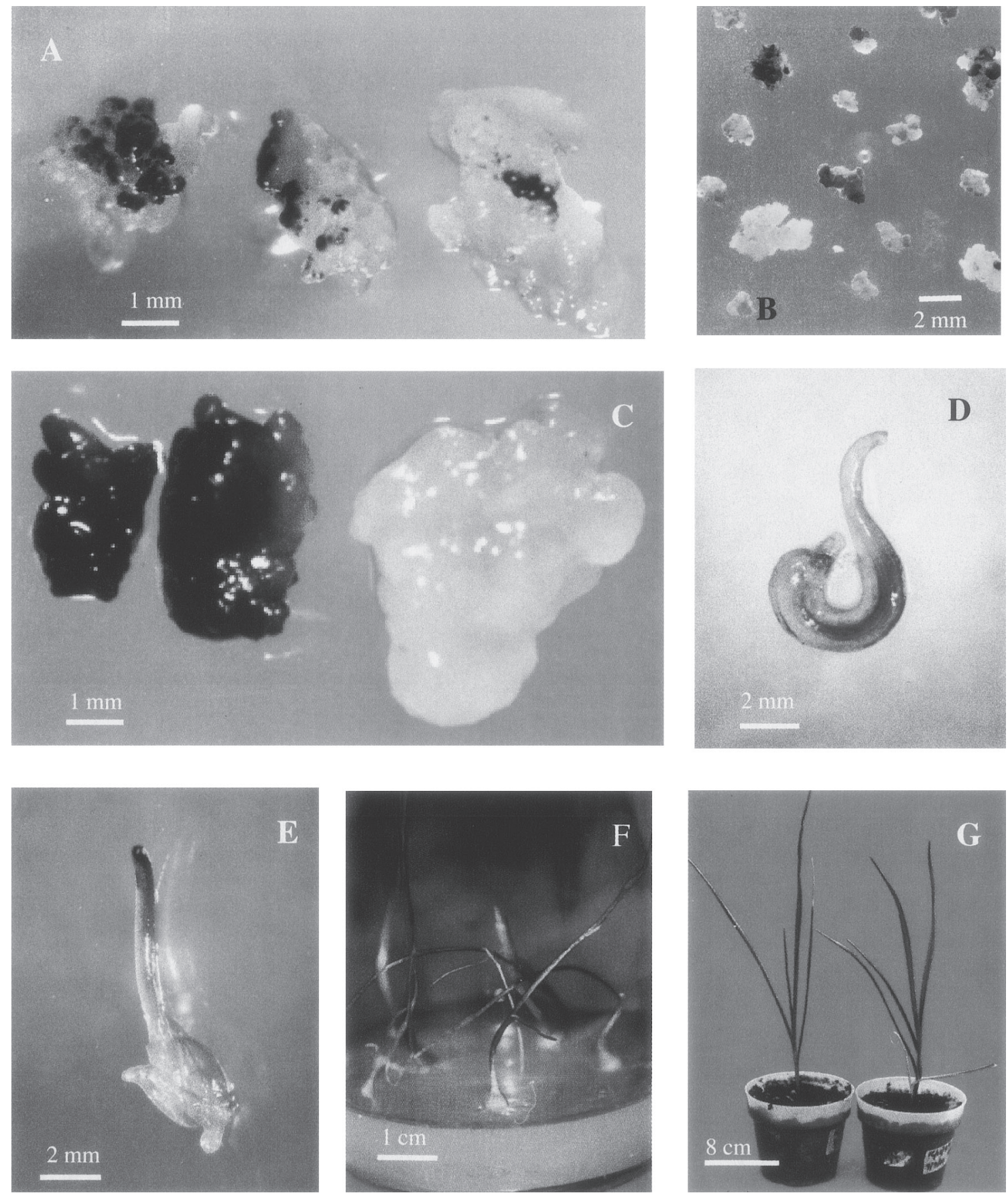

Fig. 1. Genetic transformation of garlic mediated by particle bombardment with the plasmid pWRG1515. (A) Transient expression of $\beta$-glucuronidase activity in calluses $24 \mathrm{~h}$ after bombardment. (B) Transgenic clones after 4 months on selective medium. (C) Stable expression of $\beta$-glucuronidase in transgenic clones. (D and E) Regenerated plantlets showing gusA gene expression. (F) Microbulb development from transgenic plantlets of garlic. (G) Transgenic plants of garlic established under soil conditions. 

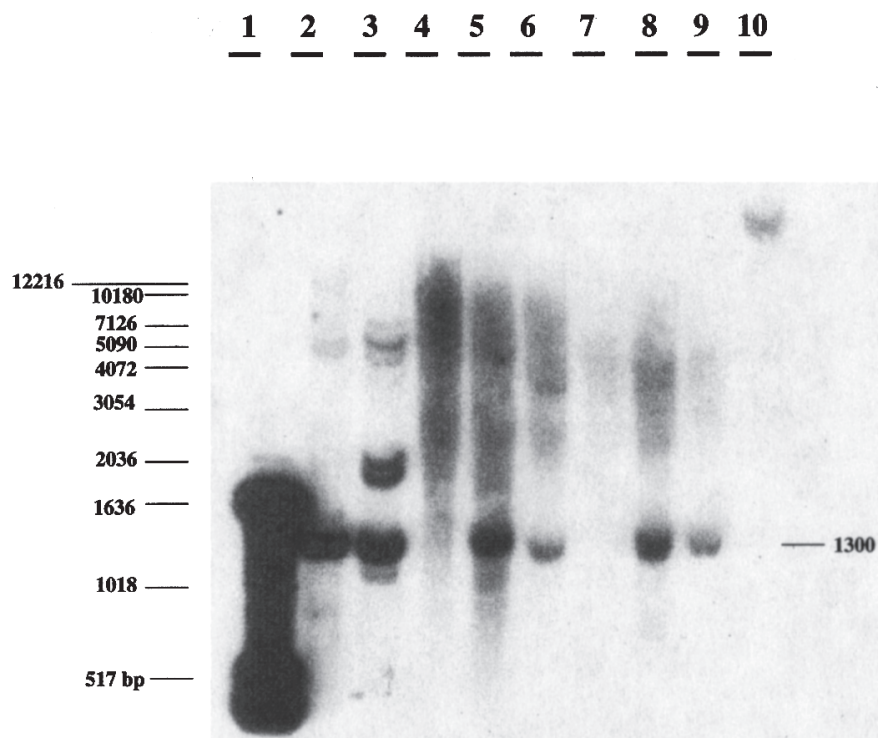

Fig. 2. Southern blot analysis of DNA from bombarded calluses with the pWRG1515 plasmid. Genomic DNAs were digested with the enzyme EcoR1. Hybridization was carried out with a 1.6-kbp XbaI fragment that contained the coding region of the hygromycin phosphotransferase gene. Lane $1=1-\mathrm{kb}$ molecular weight marker. Lanes 2 and $3=$ DNA from transgenic asparagus plants containing the pWRG1515 plasmid. Lane 4 = DNA from nonbombarded garlic callus. Lanes 5 to $9=$ DNAs from different clones of bombarded garlic calluses containing the pWRG1515 plasmid digested with EcoRI. Lane $10=$ same sample as in lane 5, but undigested.

secondary embryogenesis. Only those embryos that grew from parts of the callus nearest to the culture medium achieved full development, while others stopped development at the globular stage. Mature somatic embryos developed complete plantlets 2 weeks after being transferred to medium $\mathrm{D}$. These plantlets formed small bulbs (after 22 weeks from the start of the experiment) and were transferred to soil.

Selection of transgenic clones. Forty one percent of bombarded calluses expressed the gusA reporter gene after histochemical analysis (Fig. 1A). Barandarian et al. (1998) reported that in order to get transient $\beta$-glucuronidase activity in garlic, it was necessary to include aurintricarboxylic acid to prevent degradation of exogenous DNA by nuclease activity. Under such conditions, they obtained transient expression in only $15 \%$ of bombarded calluses. The difference observed between their experiments and ours could be due to the quality of calluses and the protocol used for particle bombardments.

Calluses were cultured on medium B with different concentrations of hygromycin B to develop a selective medium that inhibited the proliferation of nontransformed tissue. Effective selection occurred when hygromycin $\mathrm{B}$ ( 20 to $30 \mathrm{mg} \cdot \mathrm{L}^{-1}$ ) was included in the selection medium (data not shown). To obtain stably transformed lines, bombarded calluses were subcutured every 2 weeks on the same selective medium B. After 4 months under selection, the resistant and GUS-positive calluses were distinguished and were scored as transgenic clones (Fig. 1B and C). Each clone developed from a separate piece of transformed callus. Resistant calluses were yellow-green and had a high rate of growth. Conversely, nontransformed tissues turned brown and soft after 2 months of culture on selective medium containing hygromy$\operatorname{cin} \mathrm{B}$.

In this work, twenty putatively transgenic clones were recovered, from bombarded calluses. The average efficiency of genetic transformation was 2.2 clones per gram of fresh weight of callus, when calluses were bombarded with the pWRG1515 plasmid. Myers and Simon (1998) reported genetic transformation of the cultivar 'RAL27' and produced forty eight putatively transgenic lines. However they do not mention the initial number of calluses they used as starting material. Likewise, Kondo et al. (2000), reported genetic transformation of garlic using Agrobacterium tumefaciens. The transformation efficiency was fifteen transgenic shoots per one thousand co-cultured calluses. Although they also reported stable transformation, it is not possible to compare these two transformation protocols with the results presented here, because the parameters of evaluation were different.

Regeneration of transgenic plants. Plant regeneration was achieved when embryogenic calluses were transferred to medium $\mathrm{C}$ and incubated at $24{ }^{\circ} \mathrm{C}$ under a $16-\mathrm{h}$ photoperiod $\left(50 \mu \mathrm{mol} \cdot \mathrm{m}^{-2} \cdot \mathrm{s}^{-1}\right)$ for 7 weeks (Fig. 1D and 1E). Regenerated transgenic plants developed microbulbs (Fig. 1F) and were successfully established in soil conditions under a growth chamber environment (Fig. 1G). Bulbs were formed from these plants after 4 months. All regenerated transgenic plants showed leaves similar in shape and color to those of nontransformed plants.

DNA analysis. Five randomly chosen hygromycin B-resistant garlic clones were analyzed by Southern blot hybridization to confirm the presence of the $h p h$ gene in their genome. Four of the five clones gave strong signals for the expected 1.3-kbp EcoR1 fragment of the pWRG1515 plasmid using the hph coding sequence as a probe (Fig. 2, lanes 5, 6,8 and 9). Clone 3 (lane 7) was hygromycin $\mathrm{B}$ resistant and had $\beta$-glucuronidase activity, but showed a very weak hybridization signal. Nonbombarded calluses did not produce any signal (lane 4). Transgenic asparagus plants transformed with the plasmid pWRG1515 were used as a positive control (lanes 2 and 3). Comparison of DNA digested with $E c o R 1$ (lane 5) with undigested DNA (lane 10) indicated that the plasmid is integrated into the plant genome.
We propose, based on our results, that the key ponts for the establishment of a reliable protocol for genetic transformation of garlic are as follows.

1) The quality of the embryogenic calluses used. In this report, the calluses used were such that their rate of multiplication allow them to increase their biomass three times, after 4 weeks in culture (data not shown). The importance of the quality of the tissues used as starting material has been also recognized by Birch (1997) and Myers and Simon (1998).

2) The methodology of bombardment used to achieve the genetic transformation. In a previous work Barandiaran et al. (1998), bombarded garlic calluses, but did not recover any transgenic clones. However, Meyers and Simon (1998) as well as in this report showed success in regenerating transformed plants after using different protocols for genetic transformation than those reported by Barandian et al. (1998).

Myers and Simon (1998) report that only two out of five putatively transgenic lines subjected to molecular analysis $(40 \%)$, showed integration of the transgenes ( $g u s A$ and $n p t I I$ ). In contrast, in the present work we found that four of the five clones analyzed $(80 \%)$, integrated in the genome contained the $h p h$ gene. Likewise, Kondo et al. (2000) reported the stable transformation and regeneration of garlic plants mediated by Agrobacterium tumefaciens but the efficiency was as low as fifteen transgenic plants from one thousand co-cultured calluses.

Using the methodology reported here we consider that the stable genetic transformation of garlic could be a viable technique for use in breeding programs of this crop.

\section{Literature Cited}

Barandiaran, X., A. Di Pietro, and J. Martin. 1998. Biolistic transfer and expression of a uidA reporter gene in different tissue of Allium sativum L. Plant Cell. Rpt. 17:737-741.

Birch, R.G. 1997. Plant transformation: problems and strategies for practical application. Annu. Rev. Plant Physiol. Plant. Mol. Biol. 48:297-326.

Birnboim, H.C. and J. Doly. 1979. A rapid alkaline extraction procedure for screening recombinant plasmid DNA. Nucleic Acids Res. 7:1513.

Bommineni, V.R., R.N. Chibbar, R.S.S. Datla, and E.W.T. Tsang. 1993. Transformation of white spruce (Picea glauca) somatic embryos by microprojectile bombardment. Plant Cell Rep. 13:17-23.

Bower, R. and R.G. Birch. 1992. Transgenic sugarcane plants via microprojectile bombardment. Plant J. 2:409-416.

Cabrera-Ponce, J.L, L.López, N. Assad-García, C. Medina-Arevalo, A.M. Bailey, and L. HerreraEstrella. 1997. An efficient particle bombardment system for the genetic transformation of asparagus (Asparagus officinalis L.). Plant Cell Rpt.16:255-260.

Cabrera-Ponce, J.L., A. Vegas-García, and L. Herrera-Estrella. 1995. Herbicide resistant transgenic papaya plants produced by an efficient particle bombardment transformation method. Plant Cell Rpt. 15:1-7.

Casas, M.A., A.K. Kononowicz, U.B. Zehr, D.T. Thomes, J.D. Axtell, L.G. Butter, R.A. Bressan, and P.M. Hasegawa. 1993. Transgenic sorghum 
plants via microprojectile bombardment. Proc. Natl. Acad. Sci. USA 90:11212-11216.

Chee, P.P. and J.L. Slightom. 1992. Transformation of cucumber tissues by microprojectile bombardment: Identification of plants containing functional and nonfunctional transferred genes. Gene 118:255-260.

Christou, P. 1995. Strategies for variety-independent genetic transformation of important cereals, legumes and woody species utilizing particle bombardment. Euphytica 85:13-27.

Christou P., T.L. Ford, and M. Kofron. 1991. Production of transgenic rice (Oriza sativa L.) plants from agronomically important and japonica varieties via electric discharge particle acceleration of exogenous DNA into immature zygotic embryos. Bio/Technology 9:957-962.

Chu C.C., C.C. Wang, S.C. Sun, C. Hsü, K.C. Yin, C.Y. Chu, and F.Y. Bi. 1975 Establishment of an efficient medium for anther culture of rice through comparative experiments on the nitrogen sources. Sci. Sin. 18:659-688.

Eady, C.C. 2001. Allium transformation, p. 655-671. In:R.Learmonth, and G.G. Khachatourians (eds.). The handbook of transgenic plant. Marcel Deckker, New York.

Eady, C.C., C.E. Lister, Y. Suo, and D. Schaper. 1996. Transient expression of uidA constructs in vitro onion (Allium cepa $\mathrm{L}$.) cultures following particle bombardment and Agrobacterium-mediatedDNA delivery. Plant Cell. Rpt. 15:958-962.

Eady, C.C., R.J. Weld, and C.E. Lister. 2000. Agrobacterium tumefaciens-mediated transformation and transgenic plant regeneration of onion (Allium cepa L.). Plant Cell Rpt. 19:376-381.

Eriksson, T. 1965. Studies on the growth requirements and growth measurements of cell cultures of Haplopappus gracilis. Physiol. Plant. 18:976-993.
Feinberg A.P. and B. Vogelstein. 1983. A technique for radiolabelling DNA restriction endonuclease fragments to high specific activity. Ann. Biochem. 132:6-13.

Fromm, M., F. Morrish, C. Armstrong, R. Williams, J. Thomas, and T. Klein. 1990. Inheritance and expression of chimeric genes in the progeny of transgenic maize plants. Bio/Technology 8:833-839.

Hiei, Y., S Ohta, T. Komari, and T. Kumashiro. 1994. Efficient transformation of rice (Oriza sativa L.) mediated by Agrobacterium tumefaciens and sequence analysis of the boundaries of the T-DNA. Plant J. 6:271-282.

Ishida, Y., H. Saito, S. Ohta, Y. Hiei, T. Komari, T. Kumashiro. 1996. High efficiency transformation of maize (Zea mays L.) mediated by Agrobacterium tumefaciens. Nature Biotechnol. 14:745-750.

Kihara, M., K. Saeki, and K. Ito. 1998. Rapid production of fertile transgenic barley (Hordeum vulgare L.) by direct gene transfer to primary callus-derived protoplasts. Plant Cell Rpt. 17:937-940.

Kondo, T., H. Hasegawa, and M. Suzuki. 2000. Transformation and regeneration of garlic (Allium sativum L.) by Agrobacterium tumefaciens gene transfer. Plant Cell. Rpt. 19:989-993.

McCabe, D.E., B.J. Martinelli, and P. Christou. 1988. Stable transformation of soybean (Glycine max) by particle acceleration Bio/technology 6:923-926.

Murashige, T. and F. Skoog. 1962. A revised medium for rapid growth and bioassays with tobacco tissue cultures. Physiol. Plant. 15:473-497.

Myers, J.M. and Simon, P.W. 1998. Microprojectile bombardment of garlic, Allium sativum L., p. 121126. Proc. 1998 Natl. Onion (and other Allium) Res. Conf. Sacramento, Calif., 10-12 Dec.
Novak, F.J. 1990. Allium tissue culture, p. 233-250. In: H.B. Rabinowitch and J.L. Brewster (eds.) Onions and allied crops. vol. 1. CRC Press, Boca Raton, Fla.

Russell, D.R., K.M. Wallace, J.H. Bathe, B.J. Martinell, and D.E. McCabe. 1993. Stable transformation of Phaseolus vulgaris via electric-discharge mediated particle acceleration. Plant Cell Rpt. 12:165-169.

Sambrook, J., E.F. Fritsch, and T. Maniatis. 1989. Molecular cloning: A laboratory manual. 2nd ed. Cold Spring Harbor Laboratory Press, Cold Spring Harbor, N.Y.

Sanford, J.C., M.J. Devit, J.A. Russell, F.D. Smith, P.R. Harpending, M.K. Roy, and S.A. Johnston. 1991. An improved, helium-driven biolistic device. Technique 3:3-16.

Shure, M.S., S. Wessler, and N. Fedoroff. 1983. Molecular identification and isolation of waxy locus in maize. Cell 35:225-233.

Takhtajan, A. 1997. Diversity and classification of flowering plants, p. 49-69. Columbia Univ. Press, Cambridge.

Thomas, J.C., D. Adams, C. Nessler, H.J. Bohnert, and J.K. Brown. 1994. Reduced reproduction of whitefly (Bemisia tabaci) on transgenic tobacco expressing tryptophan decarboxylase. Proc. 4th Intl. Congr. Plant Mol. Biol., Amsterdam, 19-24 June. Intl. Soc. Plant Mol. Biol. Abstr.1924

Tomes, D.T., M.C. Ross, and D.D. Songstad. 1995. Direct DNA transfer into intact plant cells via microprojectile bombardment, p. 197-213. In: O.L. Gamborg and G.C. Phillips (eds.). Plant cell, tissue and organ culture: Fundamental methods. Springer Lab Manual, Springer-Verlag, Berlin.

Vain, P., B. Worland, A. Kohli, J.W. Snape, and P. Christou. 1998. The green fluorescent protein (GFP) as vital screenable marker in rice transformation. Theor. Appl. Genet. 96:164-169. 